\title{
PENERAPAN MODEL PEMBELAJARAN BERBASIS MASALAH UNTUK MENINGKATKAN HASIL BELAJAR MATERI STATISTIKA DI KELAS IX SMP NEGERI 30 MEDAN
}

\author{
Mario Henry Sihotang ${ }^{1}$, Wingston Leonard Sihombing ${ }^{2}$ \\ ${ }^{1,2)}$ Prodi Pendidikan Matematika Unimed Medan \\ soitmario7@gmail.com
}

\begin{abstract}
ABSTRAK
Penelitian ini bertujuan untuk (1) mengetahui apakah penerapan model pembelajaran berbasis masalah dapat meningkatkan hasil belajar matematika siswa pada materi statistika, (2) mengetahui bagaimana peningkatan hasil belajar siswa pada materi statistika setelah diajar dengan menerapkan model pembelajaran berbasis masalah di kelas IX SMP Negeri 30 Medan. Penelitian ini adalah penelitian tindakan kelas yang dilaksanakan dalam 2 siklus yang masing-masing siklus dilaksanakan dalam 3 kali pertemuan. Subjek dalam penelitian ini adalah siswa kelas IX-7 SMP Negeri 30 Medan tahun ajaran 2017/2018 yang berjumlah 34 orang. Berdasarkan hasil tes diagnostik diketahui hasil belajar siswa rendah dengan nilai rata-rata kelas 55,58. Setelah pemberian tindakan pada siklus I dengan menerapkan Model Pembelajaran Berbasis Masalah, tingkat ketuntasan belajar klasikal siswa adalah sedang dengan nilai rata-rata 70,14 dengan 22 siswa atau 64,7\% dari keseluruhan siswa telah mencapai ketuntasan belajar dan kemampuan guru mengelola pembelajaran adalah 2,44 dengan kategori baik. Selanjutnya, setelah pelaksanaan tindakan pada siklus II, tingkat ketuntasan belajar klasikal siswa adalah tinggi dengan nilai rata-rata kelas 80,3 dimana jumlah siswa yang telah mencapai ketuntasan belajar sebanyak 30 siswa atau 88,23\% dari seluruh siswa dan kemampuan guru mengelola pembelajaran adalah 3,21 dengan kategori sangat baik. Berdasarkan hasil penelitian tersebut dapat disimpulkan bahwa Model Pembelajaran Berbasis Masalah dapat meningkatkan hasil belajar siswa pada pokok bahasan statistika di kelas IX-7 SMP Negeri 30 Medan pada Tahun Ajaran 2017/2018.
\end{abstract}

Kata kunci : Hasil Belajar, Model Pembelajaran Berbasis Masalah, Statistika.

\section{ABSTRACT}

This study aims to (1) find out whether the application of problem-based learning model can improve students' mathematics learning outcomes on statistical materials, (2) to know how to improve student learning outcomes in statistical materials after being taught by applying problem-based learning model in class IX SMP Negeri 30 Medan. This study is a classroom action research conducted in 2 cycles, each cycle is implemented in 3 meetings. Subjects in this study were students of class IX-7 SMP Negeri 30 Medan academic year 2017/2018 which amounted to 34 people. Based on the results of the diagnostic tests are known low student learning outcomes with an average grade grade of 55.58. After giving the action in cycle I by applying Problem-Based Learning Model, student's classical learning completeness level is medium with average score 70,14 with 22 student or 64,7\% from all student have reach learn masculinity and ability of teacher to manage learning is 2, 44 with good category. Furthermore, after the implementation of the action in cycle II, the student's classical learning completeness is high with the average grade grade 80,3 where the number of students who have achieved mastery of learning as many as 30 students or $88,23 \%$ of all students and the ability of teachers to manage learning is 3,21 with very good category. Based on the results of this study can be concluded that Problem-Based Learning Model can improve student learning outcomes on the subject of statistics in class IX-7 SMP Negeri 30 Medan in the academic year 2017/2018.

Keywords: Learning Outcomes, Problem Based Learning Model, Statistics. 


\section{Pendahuluan}

Pendidikan merupakan hal yang terpenting dalam kehidupan, ini berarti bahwa setiap manusia berhak mendapat dan berharap untuk selalu berkembang dalam pendidikan. Dengan adanya pendidikan ini maka manusia atau seseorang dapat mempunyai pengetahuan, kemampuan, dan Sumber Daya Manusia yang tinggi. Pendidikan juga merupakan wahana untuk meningkatkan dan mengembangkan kualitas sumber daya manusia.

Terwujudnya pendidikan yang bermutu membutuhkan upaya yang terus menerus untuk selalu meningkatkan kualitas pendidikan. Upaya peningkatan kualitas pendidikan memerlukan upaya peningkatan kualitas pembelajaran karena muara dari berbagai program pendidikan adalah terlaksananya program pembelajaran yang berkualitas. Oleh karena itu, usaha meningkatkan kualitas pendidikan tidak akan tercapai tanpa adanya peningkatan kualitas pembelajaran. Tidak sedikit orang tua dan orang awam yang beranggapan bahwa matematika dapat digunakan untuk memprediksi keberhasilan seseorang. Peran penting yang diakui Cockroft [1] misalnya, yang menulis : "Akan sangat sulit atau tidaklah mungkin bagi seseorang untuk hidup di bagian bumi ini pada abad ke-20 ini tanpa sedikitpun memanfaatkan matematika." Untuk itu matematika sebagai disiplin ilmu perlu dikuasai dan dipahami oleh siswa sekolah agar dapat memudahkan siswa untuk mengikuti perkembangan ilmu dan teknologi. Dalam merealisasikannya diperlukan SDM yang handal dan mampu bersaing secara global. Untuk itu diperlukan kemampuan tingkat tinggi (high order thinking) yaitu berpikir logis, kritis, kreatif dan kemampuan bekerjasama secara produktif. Cara berpikir seperti itu dapat dikembangkan melalui belajar matematika.

Ada banyak alasan tentang perlunya siswa belajar matematika. Cornelius (dalam [2]), mengemukakan lima alasan perlunya belajar matematika karena matematika merupakan (1) sarana berpikir yang jelas dan logis, (2) sarana untuk memecahkan masalah kehidupan sehari-hari, (3) sarana mengenal pola-pola hubungan dan generalisasi pengalaman, (4) sarana untuk mengembangkan kreativitas, dan (5) sarana untuk meningkatkan kesadaran terhadap perkembangan budaya.

Cockroft [2] juga menambahkan, matematika perlu diajarkan kepada siswa karena (1) selalu digunakan dalam segala segi kehidupan, (2) semua bidang studi memerlukan keterampilan matematika yang sesuai, (3) merupakan saran komunikasi yang kuat, singkat dan jelas, (4) dapat digunakan untuk menyajikan informasi dalam berbagai cara, (5) meningkatkan kemampuan berpikir logis, ketelitian, dan kesadaran keruangan, dan (6) memberi kepuasan terhadap usaha memecahkan masalah yang menantang.

Matematika merupakan salah satu bidang studi yang menduduki peranan penting dalam pendidikan. Salah satu hal yang menunjukkan pernyataan tersebut adalah terlihat dari banyaknya jam pelajaran matematika di sekolah dibandingkan dengan bidang studi lain. Matematika adalah suatu alat untuk mengembangkan kemampuan berpikir, karena itu matematika sangat diperlukan baik dalam kehidupan sehari-hari maupun dalam kemajuan ilmu pengetahuan dan teknologi. Bidang studi matematika diberikan pada setiap jenjang pendidikan untuk menyiapkan siswa dalam menghadapi perkembangan dunia yang semakin maju dan berkembang pesat.

Dalam kenyataannya mutu pendidikan di Indonesia khususnya pendidikan matematika masih rendah. Hal ini sejalan dengan masih terus ditingkatkannya mutu pendidikan dengan segala macam upaya seperti perubahan kurikulum secara berkala. Salah satu cara untuk melihat mutu pendidikan matematika adalah dari tinggi rendahnya hasil belajar matematika siswa di tingkat sekolah. Hasil belajar matematika masih tergolong rendah. Guru sangatlah berperan penting terhadap hasil belajar siswa.Hasil belajar tentunya dipengaruhi oleh berbagai faktor. Salah satu faktor yang mempengaruhi rendahnya hasil belajar adalah siswa menganggap matematika sebagai pelajaran yang sangat sulit. Akibatnya siswa tidak tertarik dan merasa bosan ketika belajar matematika sehingga mengakibatkan rendahnya pencapaian hasil belajar. Hal ini didukung oleh pernyataan [2] yang menyatakan bahwa :

"Dari berbagai bidang studi yang diajarkan di sekolah, matematika merupakan bidang studi yang dianggap paling sulit oleh para siswa, baik yang tidak berkesulitan belajar dan lebih-lebih bagi siswa yang berkesulitan belajar."Mengingat pentingnya matematika, maka sangat diharapkan siswa untuk menguasai pelajaran matematika. Dalam proses belajar mengajar matematika diperlukan minat dan motivasi siswa yang tinggi guna menunjang keberhasilan pembelajaran matematika sehingga hasil belajar yang diperoleh tinggi. Namun kenyataannya hasil belajar matematika yang diperoleh siswa masih rendah. 
Daryanto [3] mengungkapkan bahwa, "Hasil nilai matematika pada ujian Nasional, pada semua tingkat dan jenjang pendidikan selalu terpaku pada angka rendah. Keadaan ini sangat ironis dengan kedudukan dan peran matematika untuk pengembangan ilmu dan pengetahuan, mengingat matematika merupakan induk pengetahuan. Selain itu, ternyata matematika pun hingga saat ini belum menjadi pelajaran yang difavoritkan. Rasa takut terhadap pelajaran matematika (fobia matematika) sering kali menghinggapi perasaan para peserta didik dari tingkat SD sampai dengan SMA bahkan hingga perguruan tinggi."

Dalam pembelajaran matematika siswa cenderung kurang berminat dan termotivasi belajar matematika. Siswa menganggap matematika itu sebagai mata pelajaran yang membosankan dan sebagian besar siswa menjadikan matematika itu sebagai momok yang menakutkan sehingga menyebabkan hasil belajar yang belum maksimal. Selain membosankan, siswa juga menganggap bahwa matematika adalah mata pelajaran yang sulit, seperti yang diungkapkan oleh [3] menyatakan :

"Fakta menunjukkan, tidak sedikit peserta didik sekolah yang masih menganggap matematika adalah pelajaran yang bikin stress, membuat pikiran bingung, menghabiskan waktu, dan cenderung hanya mengotak-atik rumus yang tidak berguna dalam kehidupan. Akibatnya, matematika dipandang sebagai ilmu yang tidak perlu dipelajari dan dapat diabaikan."

Seperti masalah yang dikemukakan di atas, pada umumnya para siswa kurang tertarik belajar matematika. Hal ini terjadi karena kenyataannya dalam pelaksanaan pembelajaran matematika masih berpusat pada guru. Seperti yang diungkapkan [4] :

"Di pihak lain secara empiris, berdasarkan hasil analisis penelitian terhadap rendahnya hasil belajar peserta didik yang disebabkan proses pembelajaran konvensional. Pada pembelajaran ini suasana kelas cenderung teacher-centered sehingga siswa menjadi pasif. Meskipun demikian, guru lebih suka menerapkan model tersebut, sebab tidak memerlukan alat dan bahan praktik, cukup menjelaskan konsep-konsep yang ada pada buku ajar atau referensi lain."

Rendahnya hasil belajar matematika ini terjadi di berbagai sekolah.

Hal ini didukung oleh pernyataan [5] yaitu :

"Rendahnya hasil belajar matematika dikarenakan proses pembelajaran yang dilakukan di dalam kelas lebih banyak didominasi oleh guru saja, sehingga ketikaguru memberikan latihan, masih ada siswa yang tidak dapat mengerjakan latihan bahkan melihat jawaban temannya. Terbukti dengan nilai ulangan harian, ujian tengah semester mereka masih di bawah Kriteria Ketuntasan Minimal (KKM). Sementara itu, siswa kesulitan dalam memahami pembelajaran matematika dikarenakan konsep dasar matematika itu tidak diterapkan oleh guru sehingga siswa tidak memiliki kreativitas dalam memecahkan masalahmasalah matematika yang diajukan padanya baik yang bersifat rutin maupun tidak."

Salah satu sekolah yang hasil belajar matematikanya rendah adalah SMP Negeri 30 Medan. Nilai hasil ulangan semester ganjil yang diperoleh siswa masih rendah. Hal ini diperoleh berdasarkan hasil wawancara dengan salah satu guru matematika SMP Negeri 30 Medan yaitu Ibu Suriani. Penyebab rendahnya hasil belajar matematika di sekolah tersebut khususnya kelas IX-7 adalah rendahnya minat siswa menerima pelajaran matematika. Kebanyakan siswa tidak suka pelajaran matematika, hal itu terlihat dari keadaan siswa yang tidak aktif dan tidak semangat ketika belajar matematika. Siswa sering merasa bingung, lupa dan kurang paham ketika ditanyai permasalahan matematika, terlebih ketika ditanyai tentang pelajaran yang lalu. Jika siswa sudah tidak mampu mengerjakan soal yang diberikan oleh guru, siswa tidak mau berusaha untuk mendapatkan jawaban dari usahanya sendiri, melainkan menunggu jawaban dari guru. Hal ini juga menjadikan program pembelajaran cenderung mengalami keterlambatan.

Observasi selanjutnya yang dilakukan peneliti berupa tes diagnostik yang diberikan pada siswa kelas IX-7 SMP Negeri 30 Medan yang berjumlah 34 siswa. Dapat dilihat bahwa mereka kesulitan dalam menyelesaikan soal. Hasil observasi menunjukkan bahwa 6 siswa $(17,64 \%)$ memperoleh nilai di atas 70, dan sebanyak 28 siswa $(82,35 \%)$ memperoleh nilai di bawah 70. Ibu Suriani memaparkan bahwa penggunaan model pembelajaran yang biasa digunakan di sekolah adalah pembelajaran konvensional yang berbentuk ceramah. Kelas masih berfokus pada guru sebagai sumber utama pengetahuan, kemudian ceramah menjadi pilihan utama metode pembelajaran. Hal ini disebabkan oleh kemampuan guru yang masih sulit mengikuti perkembangan ilmu pengetahuan dan teknologi. Proses pembelajaran yang dilaksanakan lebih banyak menekankan pada aktivitas guru daripada aktivitas siswa sehingga siswa kurang tertarik dalam proses belajar mengajar. Model pembelajaran yang digunakan 
masih kurang tepat. Hal tersebut telah menjadi suatu kebiasaan sekolah sehingga dapat menyebabkan rendahnya hasil belajar.

Siswa tidak mampu menyelesaikan permasalahan matematika dan mereka belum memahami dengan baik apa yang harus dikerjakan terlebih dahulu untuk memperoleh jawaban dari soal. Hal ini menunjukkan bahwa penguasaan siswa di kelas IX SMP Negeri 30 Medan terhadap matmatika masih kurang, sehingga hasil belajarnya masih rendah karena jauh dari nilai KKM (Kriteria Ketuntasan Minimal) yaitu 70. Ibu Suriani memaparkan bahwa penggunaan model pembelajaran yang biasa digunakan di sekolah adalah pembelajaran konvensional yang berbentuk ceramah. Kelas masih berfokus pada guru sebagai sumber utama pengetahuan, kemudian ceramah menjadi pilihan utama metode pembelajaran. Hal ini disebabkan oleh kemampuan guru yang masih sulit mengikuti perkembangan ilmu pengetahuan dan teknologi. Proses pembelajaran yang dilaksanakan lebih banyak menekankan pada aktivitas guru daripada aktivitas siswa sehingga siswa kurang tertarik dalam proses belajar mengajar. Peneliti juga melakukan observasi pada saat guru mengajar di kelas. Kegiatan yang dilakukan dalam proses belajar mengajar adalah mengerjakan soal. Selama proses pengerjaan soal tersebut, siswa disruh mengerjakan soal-soal di papan tulis dan ketika selesai dikerjakan, guru memeriksa pekerjaan siswa dan ketika pekerjaan siswa itu salah guru hanya menyatakan hasil dari pekerjaan siswa salah tanpa memberitahu pada siswa dimana letak kesalahannya. Hal ini akan berakibat siswa berulang kali melakukan kesalahan yang sama.

Dari permasalahan di atas, perlu diterapkan suatu model pembelajaran matematika yang diharapkan dapat menyelesaikan permasalahan yang dihadapi siswa. Model pembelajaran yang tepat untuk meningkatkan hasil belajar siswa adalah model pembelajaran berbasis masalah. Model pembelajaran berbasis masalah merupakan salah satu model pembelajaran yang inovatif yang dapat memberikan kondisi belajar aktif kepada siswa, melibatkan siswa untuk menyelesaikan suatu masalah melalui tahap-tahap metode ilmiah sehingga siswa dapat memberikan kondisi belajar aktif kepada siswa, melibatkan siswa untuk menyelesaikan suatu masalah melalui tahap-tahap metode ilmiah sehingga siswa dapat mempelajari pengetahuan yang berhubungan dengan masalah tersebut dan sekaligus memiliki keterampilan untuk memecahkan masalah. Arends [4] mengemukakan bahwa :

\section{Tinjauan Teori}

\subsection{Pembelajaran berbasis Masalah}

"Pembelajaran berbasis masalah merupakan suatu pendekatan pembelajaran di mana siswa mengerjakan permasalahan yang autentik dengan maksud untuk menyusun pengetahuan mereka sendiri, mengembangkan inquiri dan keterampilan berpikir tingkat lebih tinggi, mengembangkan kemandirian, dan percaya diri."

Pembelajaran Berbasis Masalah diharapkan mampu menyelesaikan permasalahan rendahnya hasil belajar matematika yang akan mengubah proses pembelajaran agar tidak lagi cenderung berpuat pada guru. [6] menyatakan bahwa :

"Pembelajaran melalui pendekatan PBM merupakan suatu rangkaian pendekatan kegiatan belajar yang diharapkan dapat memberdayakan siswa untuk menjadi seorang individu yang mandiri dan mampu menghadapi setiap permasalahan dalam hidupnya di kemudian hari. Dalam pelaksanaan pembelajaran, siswa dituntut terlibat aktif dalam mengikuti proses pembelajaran melalui diskusi kelompok. Langkah awal kegiatan pembelajaran dilaksanakan dengan mengajak siswa untuk memahami situasi yang diajukan baik oleh guru maupun siswa, yang dimulai dari apa yang telah diketahui oleh siswa."

Dalam pembelajaran ini, masalah yang dijadikan sebagai fokus pembelajaran dapat diselesaikan siswa melalui kerja kelompok sehingga dapat memberi pengalaman-pengalaman belajar yang beragam pada siswa seperti kerjasama dan interaksi dalam kelompok membuat hipotesis, merancang percobaan, melakukan penyelidikan, mengumpulkan data, menginterpretasikan data, membuat kesimpulan, mempresentasikan, berdiskusi dan membuat laporan.

\subsection{Teori belajar yang Mendukung}

Beberapa teori belajar yang melandasi model pembelajaran berbasis masalah [6], yakni sebagai berikut :

1. Teori belajar Konstruktivisme 
Dari segi pedagogis, [6] pembelajaran berbasis masalah didasarkan pada teori belajar Konstruktivisme dengan ciri :

a. Pemahaman diperoleh dari interaksi dengan skenario permasalahan dan lingkungan belajar.

b. Pergaulatan dengan masalah dan proses inquiry masalah menciptakan disonansi kognitif yang menstimulasi belajar.

c. Pengetahuan terjadi melalui proses kolaborasi negosiasi sosial dan evaluasi terhadap keberadaan sebuah sudut pandang.

\section{Teori Belajar Bermakna dari David Ausubel}

Ausubel membedakan antara belajar bermakna (meaningfull learning) dengan belajar menghafal (rote learning). Belajar bermakna merupakan proses belajar dimana informasi baru dihubungkan dengan struktur pengertian yang sudah dimiliki seseorang yang sedang belajar. Belajar menghafal, diperlukan bila seseorang memperoleh informasi baru dalam pengetahuan yang sama sekali tidak berhubungan dengan yang telah diketahuinya. Kaitan dengan pembelajaran berbasis masalah dalam hal mengaitkan informasi baru dengan struktur kognitif yang telah dimiliki oleh siswa.

\section{Teori Belajar Vigotsky}

Perkembangan intelektual terjadi pada saat individu berhadapan dengan pengalaman baru dan menantang serta ketika mereka berusaha untuk memecahkan masalah yang dimunculkan. Dalam upaya mendapatkan pemahaman, individu berusaha mengaitkan pengetahuan baru dengan pengetahuan awal yang telah dimilikinya kemudian membangun pengertian baru. Vigotsky [7] meyakini bahwa interaksi sosial dengan teman lain memacu terbentuknya ide baru dan memperkaya perkembangan intelektual siswa. Kaitan dengan pembelajaran berbasis masalah dalam hal mengaitkan informasi baru dengan struktur kognitif yang telah dimiliki oleh siswa melalui kegiatan belajar dalam interaksi sosial dengan teman lain.

4. Teori Belajar Jerome S. Bruner

Metode penemuan merupakan metode dimana siswa menemukan kembali, bukan menemukan yang sama sekali benar-benar baru. Belajar penemuan sesuai dengan pencarian pengetahuan secara aktif oleh manusia, dengan sendirinya memberikan hasil yang lebih baik, berusaha sendiri mencari pemecahan masalah serta didukung oleh pengetahuan yang menyertainya, serta menghasilkan pengetahuan yang benar-benar bermakna.

\section{Metode Penelitian}

Penelitian ini dilaksanakan di SMP Negeri 30 Medan dengan waktu pelaksanaan pada tahun ajaran 2017/2018 di kelas IX semester Ganjil. Adapun alasan pemilihan lokasi ini karena hasil belajar matematika siswa pada sekolah tersebut rendah.

Subjek dalam penelitian ini adalah siswa kelas IX-7 pada semester ganjil tahun ajaran 2017/2018, yang berjumlah 34 siswa.

Objek penelitian ini adalah penerapan model pembelajaran berbasis masalah untuk meningkatkan hasil belajar siswa pada pokok bahasan statistika di kelas IX SMP Negeri 30 Medan tahun ajaran 2017/2018.

Jenis penelitian ini adalah penelitian tindakan kelas (classroom action research) dengan menerapkan model pembelajaran berbasis masalah dengan tujuan memperbaiki mutu praktik pembelajaran di kelas. Penelitian ini bertujuan untuk mengungkap kesulitan yang dialami siswa dalam menyelesaikan permasalahan kubus dan balok serta menjelaskan upayaupaya yang dilakukan untuk meningkatkan hasil belajar matematika siswa pada pokok bahasan statistika.Penelitian ini bertujuan untuk mengungkap kesulitan yang dialami siswa dalam menyelesaikan permasalahan kubus dan balok serta menjelaskan upaya-upaya yang dilakukan untuk meningkatkan hasil belajar matematika siswa pada pokok bahasan statistika.

\section{Hasil Penelitian dan Pembahasan}

Observasi dilaksanakan ketika proses penerapan model pembelajaran berbasis masalah dalam pembelajaran matematika pada materi statistika setiap kali pertemuan. Dari lembar observasi yang telah diisi oleh observan tiap kali pertemuan, data observasi dapat 
dilihat pada lampiran. Berdasarkan perhitungan rata-rata keseluruhan aspek berada pada nilai 2,44-3,21.

Penerapan model pembelajaran berbasis masalah dapat meningkatkan hasil belajar matematika siswa.

Berdasarkan hasil penelitian, sebelum diberi tindakan rata-rata kelas adalah 55,58 dengan tingkat ketuntasan klasikal $17,64 \%$. Setelah diberi tindakan I menggunakan model pembelajaran berbasis masalah, rata-rata nilai Tes Hasil Belajar I meningkat menjadi 70,14 dengan persentase ketuntasan klasikal 64,7\%. Ini berarti terjadi peningkatan 47,06\% dari tes diagnostik yang dilaksanakan. Kemudian setelah pemberian tindakan II dimana pembelajaran masih tetap dengan model pembelajaran berbasis masalah diperoleh rata-rata Tes Hasil Belajar II siswa adalah 80,3 dengan persentase ketuntasan klasikal 88,23\% yang berarti mengalami peningkatan sebesar 23,53\% dari Tes Hasil Belajar I.

Berdasarkan hasil tes yang diberikan pada siklus I dan siklus II selama penelitian maka diperoleh tingkat ketuntasan sebagai berikut :

Tabel 1. Tingkat Ketuntasan Tes Awal, THB I dan THB II

\begin{tabular}{|l|c|c|c|}
\hline & Tes Diagnostik & THB I & THB II \\
\hline Siswa yang tuntas & $\begin{array}{c}\text { 6 Siswa } \\
(17,64 \%)\end{array}$ & $\begin{array}{c}22 \text { Siswa } \\
(64,7 \%)\end{array}$ & $\begin{array}{c}30 \text { Siswa } \\
(88,23 \%)\end{array}$ \\
\hline Siswa yang tidak tuntas & $\begin{array}{c}28 \text { Siswa } \\
(82,35 \%)\end{array}$ & $\begin{array}{c}12 \text { Siswa } \\
(35,3 \%)\end{array}$ & $\begin{array}{c}\text { 4 Siswa } \\
(11,76 \%)\end{array}$ \\
\hline Nilai rata-rata & 55,58 & 70,14 & 80,3 \\
\hline
\end{tabular}

Berdasarkan tabel di atas, dapat dilihat bahwa banyak siswa yang tuntas dalam pembelajaran mulai dari tes awal hingga tes hasil belajar II terus mengalami peningkatan yang pada awalnya hanya 6 siswa menjadi 22 hingga 30 siswa. Nilai rata-rata siswa meningkat dari tes awal yang hanya 55,58 menjadi 80,3 . Karena sebanyak $88,23 \%$ dari keseluruhan siswa telah tuntas, maka pembelajaran pada materi statistika di kelas IX-7 dengan menggunakan model pemebalajaran berbasis masalah telah tuntas.

Berdasarkan hasil tes yang diberikan dari tes awal sampai siklus II, maka tingkat penguasaan siswa dapat diperoleh. Hasil selengkapnya dapat dilihat pada tabel berikut :

Tabel 2. Deskripsi Tingkat Kemampuan Siswa Setiap Siklus

\begin{tabular}{|c|c|c|c|c|}
\hline $\begin{array}{c}\text { Tingkat } \\
\text { Penguasaan }\end{array}$ & Kriteria & Tes Diagnostik & THB I & THB II \\
\hline $90 \%-100 \%$ & Sangat tinggi & - & - & 9 \\
\hline $80 \%-89 \%$ & Tinggi & 2 & 10 & 15 \\
\hline $65 \%-79 \%$ & Sedang & 4 & 15 & 10 \\
\hline $55 \%-64 \%$ & Rendah & 10 & 7 & - \\
\hline $0 \%-54 \%$ & Sangat rendah & 18 & 2 & - \\
\hline$\sum$ & & 34 & 34 & 80,3 \\
\hline Rata-rata kelas & & 55,58 & 70,14 & $88,23 \%$ \\
\hline Persentase ketuntasan klasikal & $17,64 \%$ & $64,7 \%$ & $11,76 \%$ \\
\hline \multicolumn{2}{|l|}{ Persentase yang tidak tuntas } & $82,35 \%$ & $35,3 \%$ & 34 \\
\hline
\end{tabular}

Berdasarkan tabel di atas dapat dilihat bahwa banyaknya siswa yang memiliki tingkat penguasaan sangat rendah mulai tes diagnostik sampai tes hasil belajar II terus berkurang dari 18 siswa menjadi 2 siswa pada Tes Hasil Belajar I dan menjadi tidak ada lagi siswa yang memiliki tingkat penguasaan sangat rendah pada Tes Hasil Belajar II. Siswa yang memiliki tingkat penguasaan rendah mulai tes diagnostik sampai Tes Hasil Belajar II terus berkurang dari 10 siswa menjadi 7 siswa pada Tes Hasil Belajar I dan menjadi tidak ada lagi siswa yang 
memiliki tingkat penguasaan rendah pada Tes Hasil Belajar II. Siswa yang memiliki tingkat penguasaan sedang pada saat tes diagnostik yang hanya 4 siswa bertambah menjadi 15 siswa pada Tes Hasil Belajar I, namun berkurang menjadi 10 siswa pada Tes Hasil Belajar II. Siswa yang tidak memiliki tingkat penguasaan tinggi pada tes awal dan Tes Hasil Belajar I, namun pada Tes Hasil Belajar II terdapat 9 siswa yang memiliki tingkat penguasaan tinggi. Walaupun masih ada 4 siswa yang tidak tuntas pada Tes Hasil Belajar II, namun secara keseluruhan tingkat penguasaan di kelas ini termasuk ke dalam kategori tinggi yaitu dilihat dari rata-rata siswa pada Tes Hasil Belajar II yaitu 80,3.

Hasil penelitian ini relevan dengan penelitian [8] yang memperoleh deksripsi tentang penerapan model Problem Based Learning (PBL) dan mengetahui hasil belajar matematika siswa setelah penerapan model pembelajaran berbasis masalah. Setelah penelitian dilakukan, hasilnya adalah penerapan model pembelajaran berbasis masalah dapat meningkatkan hasil belajar siswa kelas VIII SMPN 19 Palu pada materi panjang garis singgung persekutuan dua lingkaran.

Kajian relevan yang lainnya adalah penelitian yang dilakukan oleh Bungel [9] yang meneliti Penerapan Model Pembelajaran Problem Based Learning untuk Meningkatkan Hasil Belajar Siswa Kelas VIII SMP Negeri 4 Palu pada Materi Prisma. Hasil penelitian menunjukkan juga bahwa penerapan model pembelajaran berbasis masalah pada siswa kelas VIII SMP Negeri 4 Palu dapat meningkatkan hasil belajar matematika siswa.

\section{Kesimpulan dan Saran}

Berdasarkan hasil analisis data dan hasil observasi dapat diambil kesimpulan penerapan Model Pembelajaran Berbasis Masalah dapat meningkatkan Hasil Belajar Matematika siswa kelas IX-7. Ini dapat dilihat pada tes diagnostik sebelum diberikan model pembelajaran berbasis masalah, rata-rata hasil belajar siswa adalah 55,58, hasil belajar setelah tindakan I diberikan (siklus I) nilai rata-rata kelas adalah 70,14 dan tes hasil belajar siklus II, nilai rata-rata kelas adalah 80,3. Peningkatan hasil belajar Matematika siswa setelah diterapkan Model Pembelajaran Berbasis Masalah meningkat sebesar 10,16 yaitu dari 55,58 pada siklus I sehingga menjadi 80,3 pada siklus II. Sedangkan peningkatan hasil belajar siswa secara klasikal yaitu sebesar $64,7 \%$ pada siklus I dan pada siklus II meningkat sebesar $23,53 \%$ yaitu $88,23 \%$.

\section{DAFTAR PUSTAKA}

[1] Shadiq, F., (2014), Pembelajaran Matematika Cara Meningkatkan Kemampuan Berpikir Siswa, Graha Ilmu, Yogyakarta.

[2] Abdurrahman, M., (2012), Anak Berkesulitan Belajar : Teori, Diagnosis, dan Remediasinya, Rineka Cipta, Jakarta.

[3] Daryanto, (2013). Inovasi Pembelajaran Efektif. Bandung: Yrma Widya.

[4] Trianto, (2009), Mendesain Model Pembelajaran Inovatif-Progresif : konsep, landasan, dan Implementasinya pada Kurikulum Tingkat Satuan Pendidikan (KTSP), Kencana Prenada Media Group, Jakarta.

[5] Nasution, N. R. \& Edy Surya, (2017), Perbedaan Hasil Belajar dengan Menggunakan Model Pembelajaran Berbasis Masalah dan Discovery Learning di Madrasah Tsanawiyah Negeri 2 Medan

[6] Rusman, (2012), Model-model Pembelajaran, Mengembangkan Profesionalisme Guru, PT Raja Grafindo Persada, Jakarta.

[7] Ibrahim, M. dan M. Nur. 2000. Pembelajar Berdasar Masala. Surabaya: UNESAUniversity Press. 
[8] Paloloang, M. Fachri Baharuddin, (2014), Penerapan Model Problem Based Learning (PBL) Untuk Meningkatkan Hasil Belajar Siswa pada Materi Panjang Garis Singgung Persekutuan Dua Lingkaran di Kelas VIII SMP Negeri 19 Palu, Jurnal Elektronik Pendidikan Matematika Tadulako, Vol. 2, Nomor 1

[9] Bungel, M. F., (2014), Penerapan Model Pembelajaran Problem Based Learning untuk Meningkatkan Hasil Belajar Siswa pada Siswa Kelas VIII SMP Negeri 4 Palu pada Materi Prisma, Jurnal Elektronik Pendidikan Matematika Tadulako, Vol. 2, Nomor 1 